\title{
SYNTHESIS AND STABILITY STUDY ON AN ASPIRIN DERIVATIVE WITH POTENTIAL SELECTIVE COX-2 INHIBITOR
}

\author{
Al-Mikhlafi S. A. ${ }^{a(*)}$ and Othman A.M ${ }^{\mathrm{b}}$ \\ Department of medicinal chemistr ${ }^{a}$, Department of pharmaceutics ${ }^{b}$ \\ Faculty of Pharmacy, Sana'a University
}

\begin{abstract}
The synthesis of $\mathrm{N}-$ [5- Methyl-2- (1, 3, 4 COX-2 selective inhibitor and the preliminary kinetic study for hydrolysis of this compound is studied in this paper. The compound was prepared from the corresponding aspirin and 2-amino-5-methyl-1,3,4thiadiazole in the presence of $N, N$-dicyclohexylcarbodiimide (DCC) as coupling agent .

The preliminary kinetic study for hydrolysis of this compound and the effect of $\mathrm{pH}$ on the rate of hydrolysis in buffer solution citrate-phosphate-borate/HCl was studied. The structure was confirmed by infrared, nuclear magnetic resonance (H-NMR), and elemental microanalysis assay. The compound underwent slightly hydrolysis at low and high $\mathrm{pH}$ with a fairly stabile so, provide a chance for it to be absorbed intact with highly bioavailability, longer half life, and with lower G1 toxicity.
\end{abstract}

\section{INTRODUCTION}

Non-steroidal anti-inflammatory drugs (NSAIDS) such as aspirin and selective cyclo-oxygenase-2 (COX-2) inhibitors are some of the most commonly prescribed medications worldwide, these drugs are used to treat painful inflammatory conditions such as arthritis, traumatic injuries, pain and fever ${ }^{(1,2)}$. These agents act via inhibition of the COX enzyme which catalyzes the first step

(*) Corresponding author. Tel+967 711639234.

E- Mail address: sadik1966@hotmail.com. 
of the biosynthesis of prostaglandins ${ }^{(3)}$. Two isoforms of this enzyme have been discovered. The first isoform COX-1 is constitutively expressed particularly in the gastrointestinal tract and the kidneys. It is responsible for the physiological production of prostaglandins. The other isoform COX-2 is induced during inflammation process ${ }^{(6,7)}$. The development of selective COX-2 inhibitors leads to discovery of drugs with significantly reduced renal and gastrointestinal side effects ${ }^{(8)}$.

Traditional NSAIDs inhibit both isoforms of the enzyme COX ${ }^{(8,9)}$. In studies of rofecoxib and lumiracoxib as selective COX-2 inhibitors, the absolute risk of serious upper gastrointestinal ulceration and bleeding is reduced by $50-60 \%$ or more compared to other NSAIDS ${ }^{(8,10)}$.

Recent studies have shown that small tumors of the sympathetic nervous system (neuroblastoma) "have abnormal levels of COX-2 expressed. These studies report that an overexpression of the COX-2 enzyme has an adverse effect on the tumor suppressor ${ }^{(11)}$. On the other hand, recent reviews of aspirin induced asthma (AIA) ${ }^{(12,13)}$, the use of the COX-2 preferential inhibitor nimesulide in asthmatic patients intolerant to NSAIDS ${ }^{(14,15)}$. This study discuss the importance of inhibiting prostaglandin $\mathrm{E} 2\left(\mathrm{PGE}_{2}\right)$ synthesis in $\mathrm{AlA}$, and the relative safety of NSAIDs that preferentially inhibit COX-2 (16).

Only one small study has been reported on the use of meloxicam in five patients with AIA. NSAID intolerant patients dyspnoea occurred in two with aspirin and two with ketoprofen, but three of these four had no dyspnoea with $11 \mathrm{mg}$ meloxicam (therapeutic dose $7.5-15 \mathrm{mg}$ daily) ${ }^{(17)}$.

The importance of chemical modification of commercially available traditional NSAIDS such as piroxicam [1] to produces preferential COX-2 selective inhibitors, meloxicam [2]. We were encouraged to search for novel COX-2 as selective inhibitors. By conversion of carboxyl group of aspirin to carboxamid group by conjugating the selected moiety of heterocyclic compound, 2 amino - 5-methyl -1, 3, 4-thiadiazole, may impart towards COX2 inhibitors with lower G1 toxicity, also these conjugates are 
Al-Mikhlafi S. A. et al.

similar that of isosteric functional groups of meloxicam derivatives ${ }^{(18,19)}$.<smiles>CC1=C(C(=O)Nc2ccccn2)N(C)S(=O)(=O)c2ccccc21</smiles>

[1]<smiles>Cc1cnc(NC(=O)C2=C(O)c3ccccc3S(=O)(=O)N2C)s1</smiles>

[2]

In this study the synthesis of a novel aspirin derivative compound [III] was achieved with the aim not only synthesis of selective potential COX-2 inhibitor but also to increase its the duration of action in similar to meloxicam.

\section{Chemicals and Methods}

- Aspirin crystalline powder, is kind gift from Samara Drug Industry Iraq.

- 2-Amino-5 Methyl-1,3,4-thiadiazole was purchased from Aldrich Chem. Co. Germany.

- N,N-Dicyclohexylcarbodiimide (DCC) was from Acros USA.

- Dicholromethane AR 99.5\% was from chem.-supply PTV, Italy.

- The working buffer consists of:-Citrate- phosphate- borate/ $\mathrm{HCl}$ buffer solution

- Melting points, (MP), were measured using an electrothermal melting point apparatus, and uncorrected.

- Infrared (IR) spectra, were recorded using $\mathrm{KBr}$ disc, by using Shimadzu FT- (8101 IR) Spectroscopy (Japan).

- Elemental Microanalysis CHN, were performed using an Exeter CE-440 Elemental analyzer (Germany).

Nuclear Magnetic Resonance $\left({ }^{1} \mathrm{H}-\mathrm{NMR}\right)$ spectra on Mercury $300 \mathrm{MHz}-\mathrm{H}-\mathrm{NMR}$ spectrometer ( $\delta$ PPM), Denmark 


\section{Synthetic Procedures of : \\ N - [5 - Methyl - 2 - (1, 3, 4 - Thiadiazolyl $)]$ - Acetyl Salicylamide [III] ${ }^{(20)}$}<smiles>Cc1nnc(NC(=O)c2ccccc2O)s1</smiles>

Aspirin (10 g, $55.5 \mathrm{mmol})$ was dissolved in $150 \mathrm{ml}$ methylene chloride, dicyclohexylcarbodiimide $(5.72 \mathrm{~g}, 27.7 \mathrm{mmol})$ was added. The reaction mixture was continuously stirred at room temperature for $3 \mathrm{hr}$, a white precipitate of dicyclohexylurea was formed and removed by filtration, the solvent was evaporated under vacuum, and an oily product was formed to yield anhydride compound $\mathbf{3 A}$.

Compound 3A (5 g, $14.60 \mathrm{mmol})$, 2-amino-5-methyl-1,3,4thiadiazole $(1.681 \mathrm{~g}, 14.6 \mathrm{mmol})$, zinc dust $(0.013 \mathrm{~g})$, glacial acetic acid $(1.4 \mathrm{ml}, 24.481 \mathrm{mmol})$, and dioxane $(50 \mathrm{ml})$ were placed in 100 $\mathrm{ml}$ round bottom flask, equipped with reflux condenser, boiling stones were added. The reaction mixture was refluxed for about $2 \mathrm{hr}$ with continuous stirring, and the reaction was checked by TLC to make sure that completion of reaction. The solvent was evaporated under vacuum, and the residue was dissolved in chloroform, washed, with $\mathrm{NaHCO}_{3}(10 \%, 3 \mathrm{X})$, HCL $(1 \mathrm{~N}, 3 \mathrm{X})$, and 3 times with distilled water, filtered over anhydrous sodium sulphate. The filtrate was evaporated and the residue was redissolved in ethyl acetate and filtered. The recrystallization was carried out by adding petroleum ether $\left(60-80 \mathrm{C}^{\circ}\right)$ on the filtrate until turbidity occurred and kept in cold place over night. Then the mixture was filtered while it is cold and the precipitate was collected to give compound $\mathbf{4 A}$.

Compound 4A, $(10 \mathrm{mmol})$ was dissolved in minimum volume of ethanol (95\%). The solution was cooled to $18 \mathrm{C}^{\circ}$, and then sodium hydroxide $(6 \mathrm{ml}, 12 \mathrm{mmol}, 2 \mathrm{~N})$ was added dropwise, with continuous stirring, over a period of about $30 \mathrm{~min}$. Stirring was continued at $18 \mathrm{C}^{\circ}$, during which the reaction mixture was checked by TLC, until the disappearance of methylester of compound (4A), that indicating a 
Al-Mikhlafi S. A. et al.

complete alkaline hydrolysis. Then the reaction mixture was acidified with $\mathrm{HCl}(6 \mathrm{ml}, 12 \mathrm{mmol}, 2 \mathrm{~N})$, excess of cold water was added and the crude phenolic compound was precipitated. TLC showed a single spot. The recrystallization was carried out by using ethanol and water to liberate target compound III. The synthetic pathway is illustrated in the following scheme-1 .

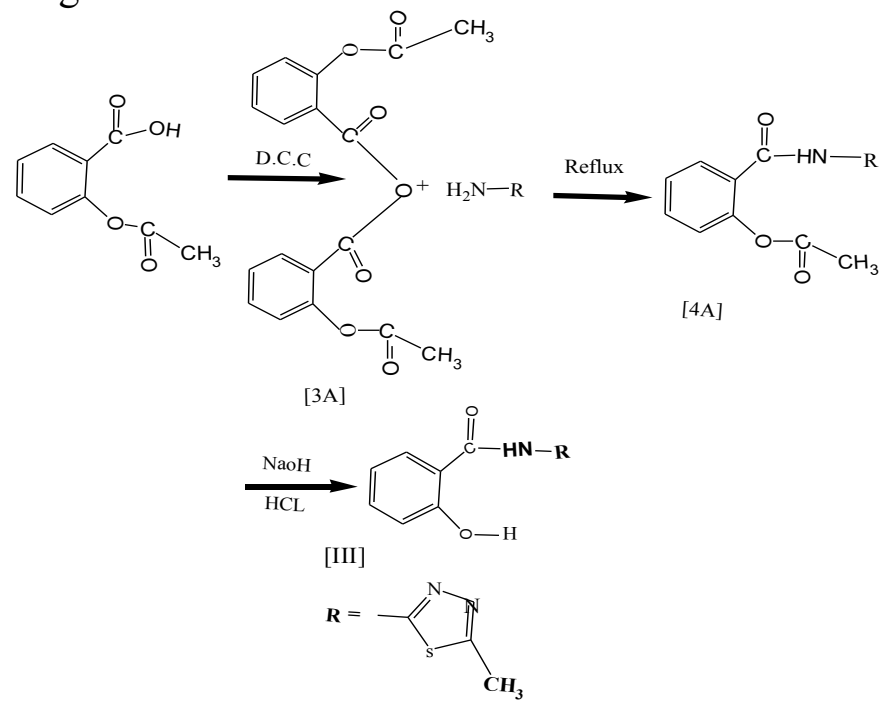

\section{Sceme-1}

\section{Preliminary Kinetic Study}

Hydrolysis of compound III at different $\mathrm{pH}$ value

The hydrolysis of compound [III], N - [5 - Methyl - 2 - (1, 3, 4- Thiadiazolyl)] - Acetyl Salicylamide, was studied in buffer solutions $\mathrm{NaOH}(1 \mathrm{~mol} / \mathrm{L})$, Citric acid $(0.92 \mathrm{~mol} / \mathrm{L})$, Phosphoric acid $(1 \mathrm{~mol} / \mathrm{L})$, Boric acid $(0.057 \mathrm{~mol} / \mathrm{L}), \mathrm{HCl}(0.1 \mathrm{~mol} / \mathrm{L})]$ of $\mathrm{pH}$ range $2-$ 9.6 at $37^{\circ} \mathrm{C}$, the rates of hydrolysis were determined by measuring the realsing amount of aspirin (III) complex using UV-spectroscopy procedure. The absorbance was measured at $\lambda_{\max } 530 \mathrm{~nm}$. The hydrolytic reaction was initiated by adding $2.5 \mathrm{ml}$ of a stock solution of derivative in dioxane $(1 \mathrm{mg} / \mathrm{ml})$ to $(5 \mathrm{ml})$ of a buffer solution to give final concentrations of $(250 \mu \mathrm{g} / \mathrm{ml})$. Samples $(0.5 \mathrm{ml})$ for each dilution was analyzed with $(2.5 \mathrm{ml})$ ferric chloride at appropriate intervals (15-120 min) for aspirin iron (III) complex. 
The appearing amount of aspirin iron (III) complex was determined by measuring the absorbance of the samples and extrapolated from standard curve.

\section{RESULTS}

\section{IDENTIFICATION AND ANALYSIS OF SYNTHESIZED COMPOUND}

IR spectra of prepared compound showed a strong stretching vibration in region $\left(3250 \mathrm{~cm}^{1}\right.$ represent $(\mathrm{N}-\mathrm{H})$.Slightly broad phenolic $(\mathrm{OH})$ stretching vibration in region $\left(3600-3350 \mathrm{~cm}^{-1}\right)$. A bands in regions $\left(1200,1325 \mathrm{~cm}^{-1}\right)$ representing phenolic $(\mathrm{C}-\mathrm{O})$ bending vibration. The presence of strong sharp band in region (1675 $\left.\mathrm{cm}^{-1}\right)$ representing the carbonyl $(\mathrm{C}=\mathrm{O})$ of secondary amide group. The presence of small sharp band in region $\left(2900 \mathrm{~cm}^{-1}\right)$ representing stretching vibration of hydrogen $(\mathrm{C}-\mathrm{H})$ methyl group.

\section{Elemental Microanalysis (CHN)}

Elemental microanalyses were performed to confirm the basic chemical structures of the synthesized agent.

C 50. 98, 50.96, H 3.82, 3.68, N 17.84, 17.81 of Calculated\& Observed respectively .

physical data of compound[ III] is White crystals, M.Wt 235.31.

The percent yield 54.5, MP263-266.

$\mathbf{R}_{\mathbf{f}}$ values (T LC) of synthesized compound III. 0.66, 0.72, 0.76 at solvent systems

A. Cyclohexane: chloroform: acetic acid (40:50:10) 0.67

B. Methanol: acetic acid : ether: benzene (1:18:60:20) 0.69

C. Methanol: ammonia $(100: 1.5) 0.74$ respectively

D.

\section{${ }^{1} \mathrm{H}-\mathrm{NMR}$ Spectroscopy of Compound [III]}

Table-1 of ${ }^{1} \mathrm{H}-\mathrm{NMR}$ spectral data for compound III , showed that, the spectra was consistent with compound structural formula with the following characteristic chemical shifts 
Al-Mikhlafi S. A. et al.

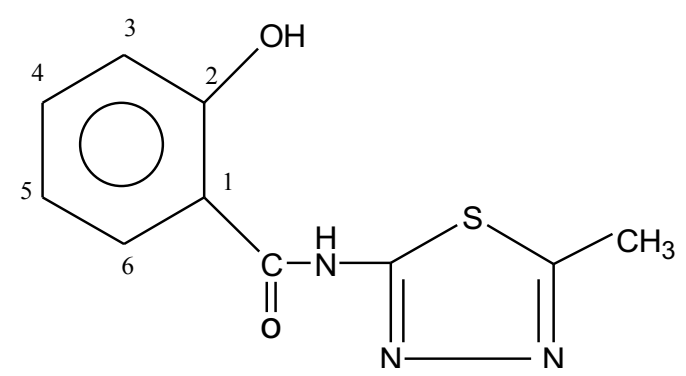

Table-1 of ${ }^{1} \mathrm{H}-\mathrm{NMR}$ data of compound-III:

\begin{tabular}{|c|c|c|c|c|}
\hline \multirow[b]{2}{*}{ Compound } & \multicolumn{2}{|c|}{ Aromatic } & \multicolumn{2}{|c|}{ Aliphatic } \\
\hline & Phenyl & $\begin{array}{c}\text { Heterocycli } \\
\text { c }\end{array}$ & $\begin{array}{c}\mathbf{X}-\mathbf{H}(\mathbf{X}= \\
\mathbf{O}, \mathbf{N})\end{array}$ & $\mathrm{CH}_{3}$ \\
\hline III & $\begin{array}{c}7.93(1 \mathrm{H}, \mathrm{d} \text {, proton }) \\
\text { at } 6 \text { position }) \\
7.47(1 \mathrm{H}, \mathrm{m}, \\
\text { proton }) \text { at } 3 \text { position } \\
7.3(2 \mathrm{H}, \mathrm{m} \text {, proton } \\
\text { at } 4 \text { and } 5 \text { position }\end{array}$ & - & $\begin{array}{c}4.12(2 \mathrm{H}, \\
\text { bs }) \\
\text { exchangeab } \\
\text { le with } \mathrm{D}_{2} \mathrm{O}\end{array}$ & $\begin{array}{c}2.5 \\
(3 \mathrm{H}, \\
\mathrm{s})\end{array}$ \\
\hline
\end{tabular}

Deuterated dimethylsulfoxide (DMSO) was used as solvent.

The chemical shifts are expressed in $\delta$-values (PPM); and the signals are defined as singlet (s), broad singlet (bs), doublet (d), triplet $(\mathrm{t})$, quartate $(\mathrm{q})$ and mutiplet $(\mathrm{m})$.

Hydrolysis of compound III at different $\mathrm{pH}$ value.

The rate of hydrolysis was slightly influenced by $\mathrm{pH}$, the maximum rate of hydrolysis was occurred at pH5.6 (t $1 / 2=1686$ minutes) and at pH8.6. (t $1 / 2=2585$ minutes) in acidic and basic media respectively. This was observed when Kobs is plotted against pH.( Figure-1). 


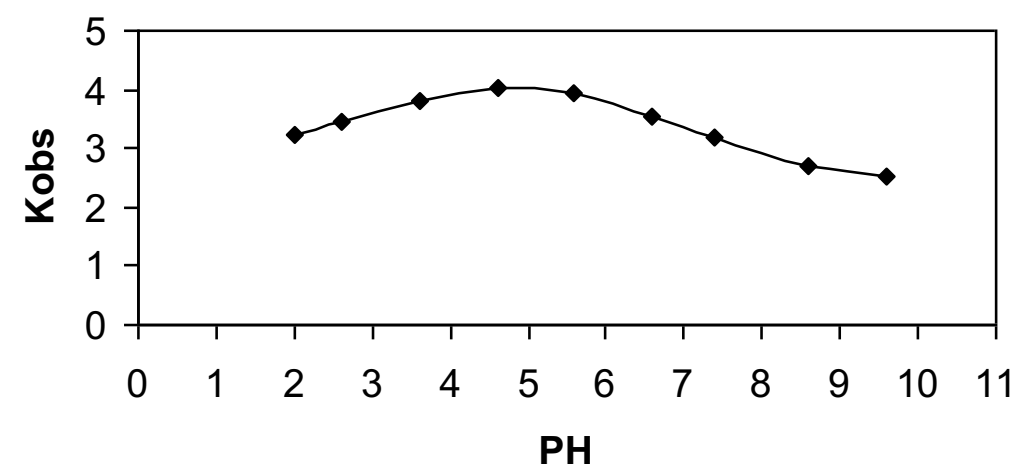

Figure-1 represent PH- rate profile for compound (III) in aqueous buffer solution at $37^{\circ} \mathrm{CO}$.

\section{DISCUSSION}

Synthetic Approach of N-Substituted Salicylamide Derivatives include:

a. The formation of $3 \mathrm{~A}$ intermediate obtained when two moles of aspirin was coupled together to generate the key intermediate $3 \mathrm{~A}$ by using 1 mole of DCC as coupling agent. This coupling agent act as a condensing agent for amide bond formation during peptide synthesis ${ }^{(21,23)}$.

The mechanism of reaction involves the addition of carboxylic acid containing group of aspirin to DCC to form a very good reactive key intermediate $\mathbf{3 A}$. The possible mechanism of reaction as shown in scheme-2

b. Coupling of the key intermediate $3 \mathrm{~A}$ with amino group of heterocyclic compound.

This procedure is analogous to that reported by Vogel ${ }^{(24)}$ for preparation of amide linkage. The acylation of anhydride $\mathbf{3 A}$ with amino group of heterocyclic compound was faster than the using of obnoxious acylchloride. The presence of zinc dust as catalyst acceleration of reaction occurred. This reaction is an example of 
Al-Mikhlafi S. A. et al.

nucleophilic reaction in which the nucleophile $\left(-\mathrm{NH}_{2}\right)$ is added to carbonyl carbon of anhydride in slightly acidic media (by adding glacial acetic acid) and presence of zinc as catalyst. The proposed mechanism as shown in scheme-3

c. hydrolysis of ester compound.

The alkaline hydrolysis of esteric compounds $\mathbf{4 A}$, by base $(\mathrm{NaOH})$ lead to production of target compounds [III]. The base used to promote hydrolysis of ester by providing the strongly nucleophilic agent $(\mathrm{OH}$ ion), this reaction is essentially irreversible, since a resonance stabilizing carboxylate. $\mathrm{HCl}$ was added to liberate acid and phenolic compound from their salts. Ethanol $95 \%$ was used as solvent; the temperature of the reaction was kept below $20^{\circ} \mathrm{C}$ to avoid hydrolysis of amide linkage ${ }^{(25)}$.

Elemental microanalyses $(\mathrm{CHN})$ was revealed a good reasonable agreement of the basic chemical structures of the synthesized agent with calculated percentages.

${ }^{1} \mathrm{H}-\mathrm{NMR}$ spectral data for compound III showed that, the spectral data was consistent with compound structural formula as shown in table-1.

\section{SPECTROPHOTOMETRIC ANALYSIS OF COMPOUND III}

A colored complex is formed from salicylic acid that result from the hydrolysis of compound III with iron (III) ion. The intensity of the color is directly related to the concentration of this agent Therefore spectrophotometric analysis has been used. The addition of acidified iron (III) ion produces the violet tetraaquosalicylatroiron (III) complex as showed in scheme -4

Stability of N - [5 - Methyl- 2 - (1, 3, 4 - Thiadiazolyl)] - Acetyl Salicylamide in aqueous buffer solution (Compound III ).

The hydrolysis of this compound was studied in citrate-phosphate-borate/HCl (TEORELL and STENHAGEN) over $\mathrm{pH}$ values range (2-9.6). The compound was incubated at different $\mathrm{pH}$ values at $\left(37^{\circ} \mathrm{C}\right)$ and an aliquot half $\mathrm{ml}$ of each sample was taken at certain intervals $(15 \mathrm{~min}$ ) and the absorbance was measured by UVspectroscopy at $\lambda_{\max } 530$. 


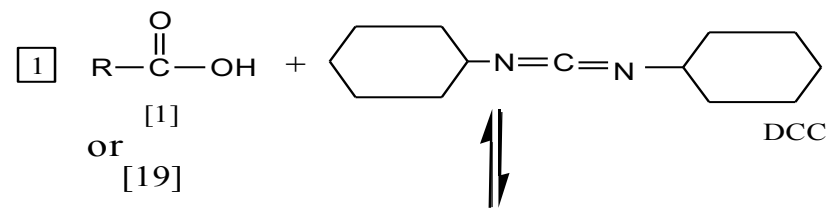

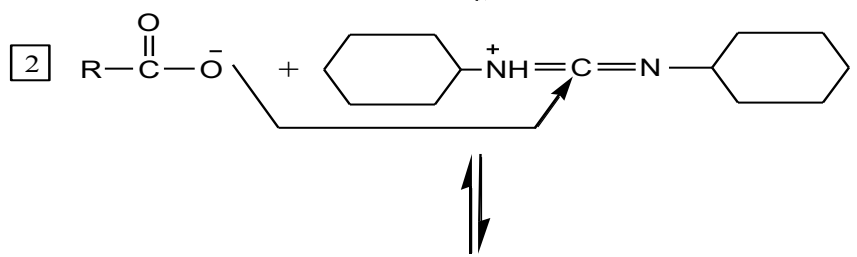

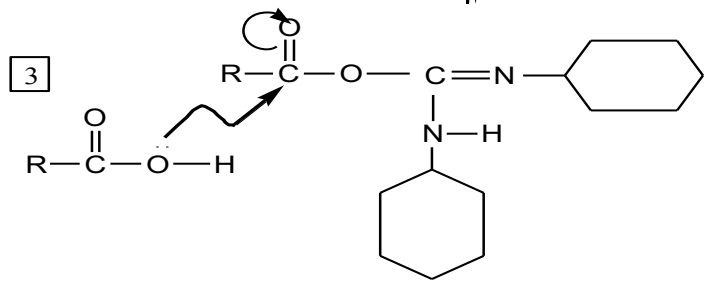

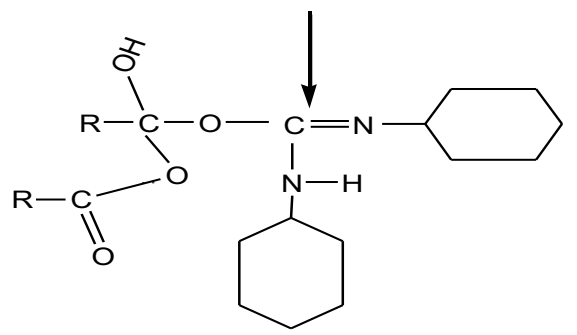

scheme-2

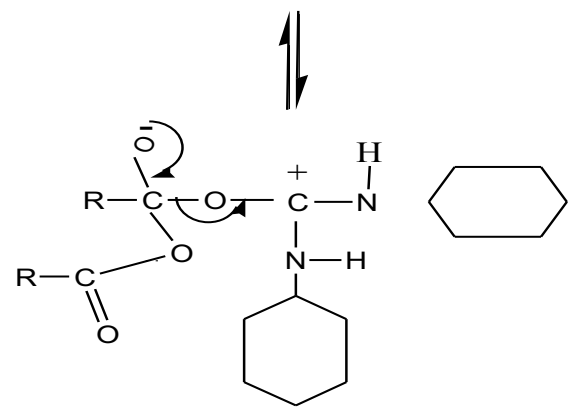




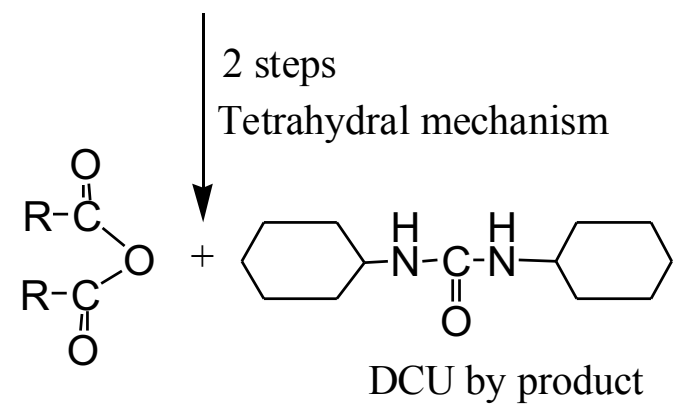

$[4 \mathrm{~A}]$
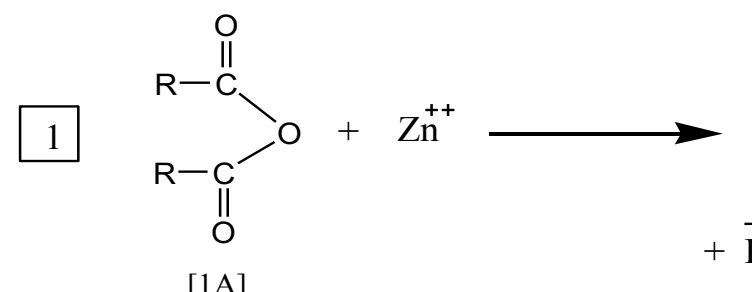

$+\overline{\mathrm{R}}-\mathrm{NH}_{2}$

$$
\mathrm{R}-\stackrel{\mathrm{O}}{\mathrm{C}} \mathrm{O}^{-}+\underset{\mathrm{R}}{\mathrm{O}}-\underset{\mathrm{O}}{\mathrm{C}}-\mathrm{H}-\mathrm{R}
$$

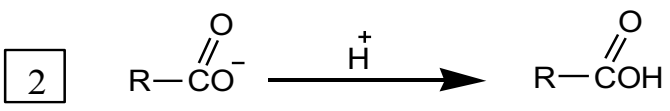

scheme-3
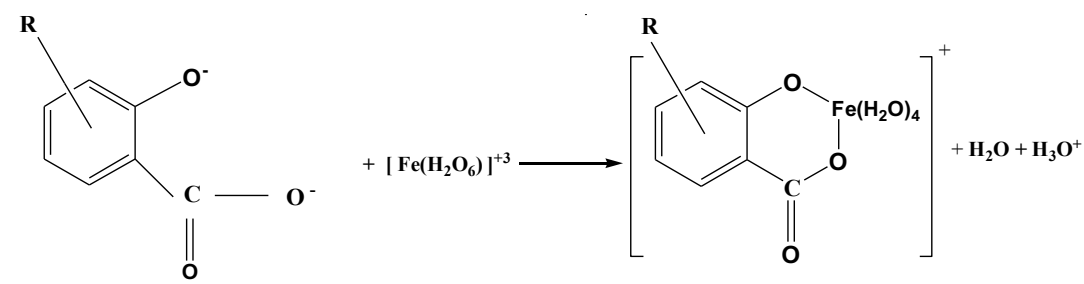

scheme-4 
The remaining amount of the drug was calculated by measuring the absorbance which was extrapolated on the standard curve.

The kinetic data obtained from this study predicate that the prepared compound has very good stability in aqueous buffer solutions at $\mathrm{pH}$ range (2-9.6)as shown in figure-1.

The hydrolysis followed first order kinetic since, the plot resulted in straight line relationship between time and Log concentration.

$\mathrm{K}$ observed rate $\left(\mathrm{K}_{\mathrm{obs}}\right)$ constant was calculated from equation (1)

$$
\text { Slope }=\frac{K_{\text {obs }}}{2.303}
$$

The period of time needed to hydrolysis $(50 \%)$ of this compound ( $\left(t \frac{1}{2}\right)$ was also determined using equation (2).

$$
t^{1 / 2}=\frac{0.693}{K_{\text {obs }}}
$$

The rate of hydrolysis showed a slightly influenced by $\mathrm{pH}$, the maximum rate of hydrolysis was occurred at $\mathrm{pH} 5.6$ ( $\mathrm{t} 1 / 2=1686$ minutes) and at $\mathrm{pH} 8.6$. ( $\mathrm{t} 1 / 2=2585$ minutes) in acidic and basic media respectively. Therefore, this drug may be absorbed intact from GIT and behave as COX-2 inhibitors.

Conclusion the anti-inflammatory compound N- [5- Methyl- 2- (1, 3, 4 - Thiadiazolyl)]- Acetyl Salicylamide with potential selective COX-2 was synthesized and preliminary kinetic study was carried out. The rate of hydrolysis as a function of $\mathrm{pH}$ was studied for this compound. It was found that the prepared compound underwent very partial hydrolysis at low $\mathrm{PH}$, specially at $\mathrm{pH} 5.6$ (t $1 / 2=1686$ minutes) and at high $\mathrm{pH}$ specially at $\mathrm{pH} 8.6$. (t $1 / 2=2585$ minutes)with a fairly stable so, provide a chance for its absorption intact with highly bioavailability, and exerts as a COX-2 selectivity with longer half life. 


\section{REFERENCES}

1. Goodman SB, Ma T, Genovese M, Lane Smith R. COX2 selective inhibitors and bone. Int. J. Immunopathol. Pharmacol. 2003, 16;3,201-205.

2. Chang Ha Park, Xavier Siomboing, Said Yous, Bernard Gressier, Michel Luyckx Pilippe Chavatte .Investigation of new lead structures for the design of novel cox-2 inhibitors. J. Med. Chem. 2002; 37, 461-468.

3. Dannhardt G, Kiefer W. Cyclooxygenase inhibitors-current status and future prospects.. Eur. J Med. Chern. 2000, 36,109126.

4. Coogan PF, Rosenberg L, Palmer JR, et al. Nonsteroidal antiinflamrnatory drugs and risk of digestive cancers at sites other than the large bowel. Cancer Epiderniol. Biomarkers Proc. 2000; 9: 119-123.

5. Coogan PF, Rosenberg $\mathbf{L}$, Louik $\mathbf{C}$, et al. NSAIDS and risk of colorectal cancer according to presence or absence of family history of the disease. Cancer Causes Control 2000; 11: 249255.

6. Schnitzer TJ, Burmester GR, Mysler E, Hochberg MC, Doherty M, Ehrsam E, et al. Comparison of lumiracoxib with naproxen and ibuprofen in The Therapeutic Arthritis Research and Gastrointestinal EventTrial (TARGET), reduction in ulcer complitions: randomised controlled trial. Lancet 2004; 364,665674.

7. Farkouh ME, Kirshner H, Harrington RA, Ruland S, Verheugt FW, Schnitzer TJ, et al. Comparison of lumiracoxib with naproxen and ibuprofen in The Therapeutic Arthritis Research and Gastrointestinal Event Trial (TARGET), cardiovascular outcomes: randomised controlled trial. Lancet 2004; 364, 675-684.

8. Bombardier C, Laine L, Reicin A, Shapiro D, BurgosVargas R, Davis B, et al. Comparison of upper gastrointestinal toxicity of rofecoxib and naproxen in patients with rheumatoid arthritis. VIGOR Study Group. N. Engl. J. Med. 2000;343: $1520-1530$

9. Lau, Land M. Hansford, L.Cheng, M.Hang and S. Baruchel, D. Kaplan and M.Irwin. Cyclooxygenase inhibitors modulate the pathway and enhance chemotherapyinduced apoptosis in neuroblastoma.Oncogene doi.2006; 10, p53 
10.Szczeklik A, Stevenson DD. Aspirin-induced asthma: advances in pathogenesis and management. J. Allergy Clin. Immunol. 1999;104, 5-13.

11. Gryglewski RJ., Vane J, Botting. .Aspirin-induced asthma and cyclooxygenases. J. William Harvey Press and Kluwer Academic Publishers, 1998; 99-107.

12. Senna GE, Passalacqua G, Andri G, et al. Nimesulide in the treatment of patients intolerant of aspirin and other NSAIDs. Drug Safety 1996;14,94-103

13. Bennett A, Villa G. Nimesulide: a nonsteroidal antiinflammatory drug that preferentially inhibits cyc100xygenase-2, and has various unique pharmacological activities. Expert Opinion on Pharmacotherapy, 2000; 1, 277-286.

14. Szczeklik A, Nizankowska E, Bochenek G, Nagraba K, Mejza F, Swierczynska M. Nimesulide: a nonsteroidal antiinflammatory drug that preferentially inhibits cyclooxygenase-2, and has various unique pharmacological activities. Clin. Exp. Allergy 2001; 31,219-225.

15. Kosnik M, Music E, Matjaz F, et al. Safety of a specific COX-2 inhibitor in aspirin-induced asthma. Allergy 1998; 53, 1231-1233.

16. John, RV, Regina MB. The future of NSAIDS therapy :selective cox-2 inhibitors . Internal J. of Clinc. Practice. 2000; 54, 7-9

17. Botten, WW. Scientific rational for specific inhibition of cox-2. $\boldsymbol{J}$. Rheumatol. 1998; 25, 2-7

18. Patoia I, Santucci, I, Furon, P, Dionisi, MS. A four-week, double-blind, parallel-group study to compare the gastrointestinal effects of meloxicam $7.5 \mathrm{mg}$, meloxicam $15 \mathrm{mg}$, piroxicam $20 \mathrm{mg}$ and placebo by means of faecal blood loss, endoscopy and symptoms evaluation in healthy volunteers. Br. J. Rheumatol. 1996; 35, 61-67.

19. Pradip K, Banerjee and Gordon L. Amidon, Physicochemical property modification strategies based on enzyme substrate specificities I: Rationale, synthesis, and pharmaceutical properties of aspirin derivatives.Journal of Pharmaceutical Science. 1981; 70, 1299-1303

20. Sheehan JC, and Hess GP. A new method of forming peptide bonds. J. Am. Chem. Soc. 1955; 77, 1067-1068.

21. Vogel, A.I, "Vogel's textbook of practical organic chemistry", 4th Ed. Longman, New York. 1978; P. 682-683.

22. Ingold, CK, "Structure and mechanism in organic chemistry", 2nd Ed. Cornell University Press USA. 1969; P. 1129-1131. 